\title{
Commentary on the journal of Lourens Lourenszoon (1618-1625) and his stay among the Arocouros on the Lower Cassiporé River, Amapá (Brazil) \\ Comentário sobre o relato de Lourens Lourenszoon (1618-1625) e sua estadia entre os Arocouros no baixo rio Cassiporé, Amapá (Brasil)
}

Neil L. Whitehead'

\begin{abstract}
This commentary presents an overview of the place of Lourens Lourenszoon's account of his captivity among the Arocouros (Palikur) Indians in relation to other contemporary sources on the native peoples of Guyana. In particular the claims as to witnessing of both cannibalism as well as the capture of a 'headless-man' provide a rich context in which to situate broader issues of ethnographic epistemology and eye-witness observation. Such marvels and monstrosities are closely associated with early wring on the Americas and in this way the account of Lourens Lourenszoon is an important addition to the debates on interpretation of historical documents across cultural space. This new translation also provides important demographic and geographical information on the situation of the native population of the Cassiporé River and region of Amapá (Brazil) in the early seventeenth century that can inform further archaeological, ethnohistorical and ethnographic investigation.
\end{abstract}

Keywords: Colonialism. Amerindians. Guyana. Amapá. Cassiporé River. Ethnohistory.

Resumo: $\bigcirc$ comentário apresenta um panorama sobre o lugar do relato da captura de Lourens Lourenszoon pelos índios Arocouros (Palikur) em relação com outras fontes contemporâneas sobre os povos nativos da Guiana. Em particular, a alegação de ter testemunhado tanto o canibalismo quanto a captura do 'homem-sem-cabeça' proporciona um rico contexto para situar temas mais amplos da epistemologia etnográfica e da observação de testemunhos oculares. Essas maravilhas e monstruosidades estão associadas com distorções antigas sobre as Américas e, nesse sentido, o relato de Lourens Lourenszoon é uma importante adição aos debates sobre interpretação de documentos históricos através do espaço cultural. Essa nova tradução também proporciona importante informação demográfica e geográfica sobre a situação da população nativa do rio Cassiporé e da região do Amapá (Brasil) no início do século XVII, que pode auxiliar outras investigações arqueológicas, etno-históricas e etnográficas.

Palavras-chaves: Colonialismo. Ameríndios. Guiana. Amapá. Rio Cassiporé. Etno-história.

University of Wisconsin-Madison. Department of Anthropology. Madison, Wisconsin, United States of America (nlwhiteh@wisc.edu).

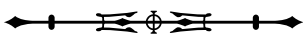


The journal of Lourens Lourenszoon is a fascinating, perplexing, informative and important document relating to the very earliest period of European settlement along the Atlantic coast north of the Amazon. The translation given here by Martijn van den Bel is both elegant and timely, since it allows scholars without their linguistic skills access to a significant historical source that has otherwise been very little know amongst scholars.

At the same time the nature of Lourens Lourenszoon's account raises fundamental issues of hermeneutic approaches to historical documents, particularly those that represent the indigenous cultures of South America. In his account Lourens relates many factual details of the locations and life styles of the Arocouros, plausibly identified by the translator as ancestral Palikur populations, but also includes reference to an encounter with a headless-man. This bizarre claim in fact is deeply embedded in the travel literatures of the region, being first mentioned by Walter Raleigh in his account of the "Large Rich and Bewtiful Empyre of Guiana", published in 1595 (Whitehead, 1997). Raleigh tells us the native term in Orinoco for this monstrous race of beings was Ewaipanoma and that they inhabited the Caura River, a southern tributary of the Orinoco. An illustration of the Ewaipanoma appears on De Bry's 1599 map of Guyana (Figures 1 to 3 ).

While these understandings of native accounts of the Ewaipanoma appear to us as incredible and fantastic,

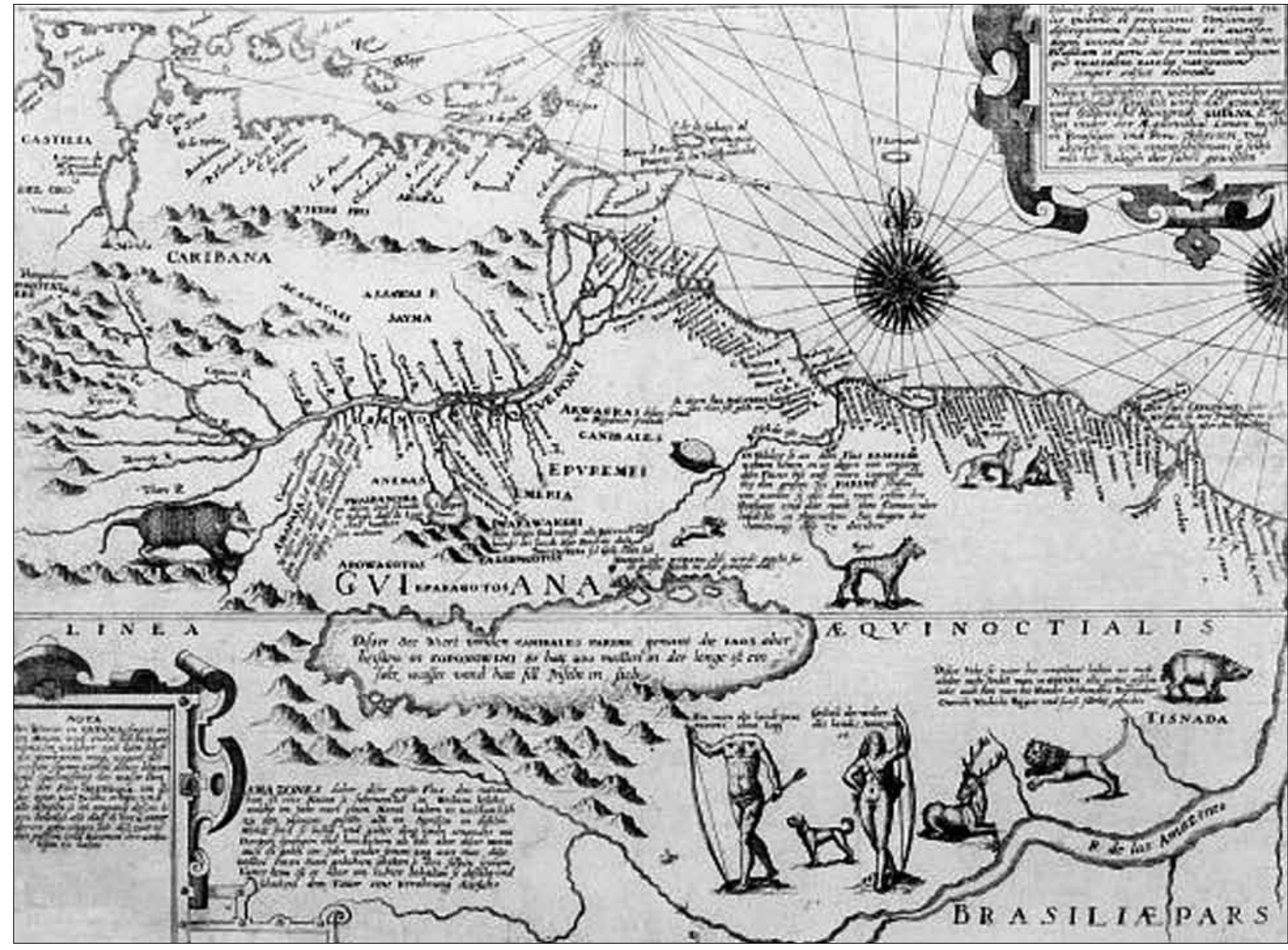

Figure 1. Guyana, from Theodor De Bry, "America”, part 5, plate 3, Frankfurt, 1599.

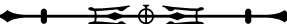




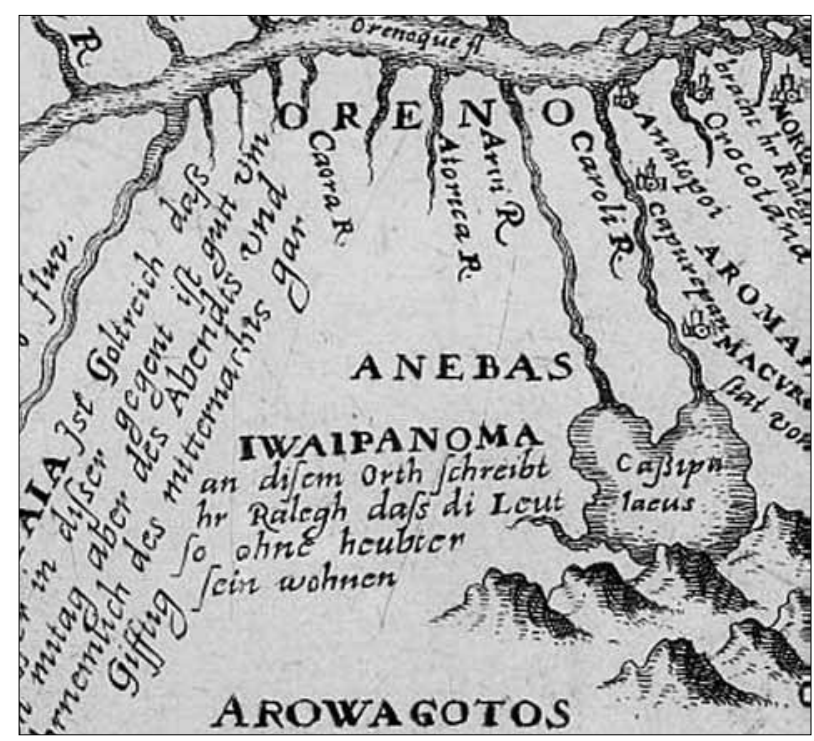

Figure 2. Location of the Iwaipanoma on the Orinoco River.

scholars have show that European and indigenous expectations as to the possibility of monstrous races or the range of human physical variety, in fact converge on certain key tropes, such as men with heads in their chests, or whose feet point backwards, or who have dog heads, and notoriously those who are cannibals. It is not necessary to rehearse that literature here ${ }^{1}$ but it is relevant to appreciate that Lourens's account of the strange creatures he saw, and one of whom was captured and beaten to death by his captors, resonates with established writings on the region.

It is tempting to try and suggest an experiential context for Lourens's claim, perhaps what he saw was a sloth? - but this poorly accords with his account of their fishing by the river bank or the wars that the Arocouros said they pursued with these strange beings. In this way we are brought to the key hermeneutic issues facing modern interpreters of the $16^{\text {th }}$ century accounts - were these claims ones of factuality or were they discursive claims meant to establish the plausibility of the account overall? For the modern reader establishing credibility through the claim to have seen incredible events does not appear as a convincing strategy. However, claims as to the existence of cannibals persisted in the way that those as to Amazons or Ewaipanoma did not, despite persistent and even contemporary ethnographic accounts of such marvels.

In short, in order to avoid the conclusion that such accounts as Lourens's, because of these marvelous claims, are to be taken as wholly unreliable, a better hermeneutical approach is to see such claims as part of the authenticating detail that was found convincing at the time. Moreover, as the translator's own annotations clearly demonstrate, many of Lourens's observations are borne out by the archaeological record that is currently emerging from the Amapá region where he was captive, as well as by other contemporary accounts of the migrations of indigenous populations away from the epicenters of contact with the Spanish, as in the case of the Yaos led from Trinidad to this are by the supreme leader Anacajoury.

Lourens also invokes the issue of cannibalism, both through his account of the crew's survival cannibalism, in which he and others refused to participate in, leading to the break up of the shipwrecked crew; and also in his account of the cannibalism of their enemies by the Arocouros. As with the mater of headless-men we cannot easily reconstruct the experiential context for Lourens's observations but the sacral manipulation of the human body was certainly as important to indigenous American spirituality as it was to contemporary Christian theology, which is what made this issue perennial and laden with ideological significance for sixteenth and seventeenth century travelers and writers.

Nearly seventy years prior to Lourens's captivity one of the most famous accounts of cannibal captivity was published by the German Hans Staden (Staden, 2008). His account was immediately translated into Dutch and appears prominently in De Bry's 1599 collection of voyages to South America. It seems quite possible that

See for example Mason (1990), Greenblatt (1992), Hulme (1992), and Whitehead (2008).

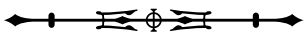




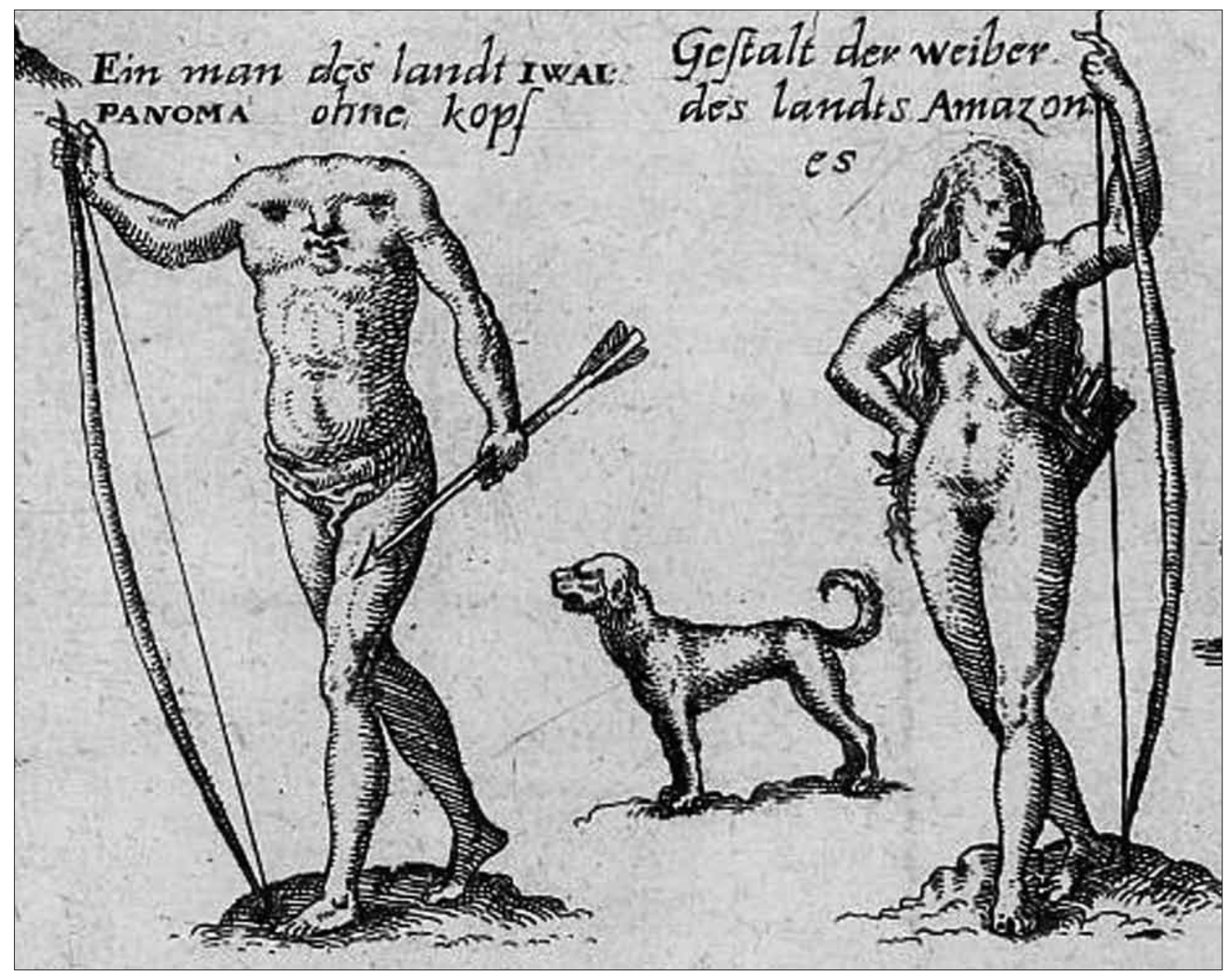

Figure 3. Details showing Iwaipanoma and Amazons.

if not Lourens himself then certainly his readers would have already known of this account and the association of 'America' with 'cannibals' would have been an established part of the European cultural imaginary. Lourens's account thus echoes a number of key incidents in common with that of Hans Staden, including the attempt by a chief of the Arocouros to have him eat human flesh and his efforts to convince them of the error of their ways. Equally, as with the account of Hans Staden, the published version was derived from an oral interrogation by the promoters of his voyage, in the case of Lourens the High Lords of the West India Company in Amsterdam.
For all these reasons the account of Lourens Lourenszoon is an important and welcome addition to the materials relating to this period and the processes of European occupation and colonization of the Guyana region (Whitehead and Alemán, 2009). Read within this broader context of European accounts Lourens's clearly adds important details of the Amapá region at the close of the $16^{\text {th }}$ century, even as the rhetorical and discursive construction of the account conforms to wider patterns of textual representation and verisimilitude. The translator is to be congratulated for inserting this most interesting document into wider debates on the discovery of America.

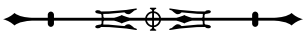




\section{REFERENCES}

GREENBLATT, Stephen. Marvelous Possessions: The Wonder of the New World. Chicago: University of Chicago Press, 1992.

HULME, Peter. Colonial Encounters: Europe and the Native Caribbean 1492-1797. London: Routledge, 1992.

MASON, Peter. Deconstructing America: Representations of the Other. London: Routledge, 1990.

STADEN, Hans. Hans Staden's True History. An Account of Cannibal Captivity in Brazil. Edited by Neil L. Whitehead and Michael Harbsmeier. Durham \& London: Duke University Press, 2008.
WHITEHEAD, Neil L. Introduction. In: STADEN, Hans. Hans Staden's True History. An Account of Cannibal Captivity in Brazil. Edited by Neil L. Whitehead and Michael Harbsmeier. Durham \& London: Duke University Press, 2008.

WHITEHEAD, Neil L. (Ed.). The Discoverie of the Large, Rich and Bewtiful Empire of Guiana by Sir Walter Ralegh. Norman: Oklahoma University Press, 1997.

WHITEHEAD, Neil L.; ALEMÁN, Stephanie W. (Eds.). Anthropologies of Guayana: Cultural Spaces in Northeastern Amazonia. Tucson: University of Arizona Press, 2009.

Recebido: 22/07/2009 Aprovado: 26/07/2009 